\title{
Adiponectin receptor expression in the human adrenal cortex and aldosterone-producing adenomas
}

\author{
GIAN PAOLO ROSSI ${ }^{1}$, DANIELE STICCHI ${ }^{1}$, LUISA GIULIANI ${ }^{1}$, PAOLO BERNANTE ${ }^{2}$, \\ SILVIA ZAVATTIERO $^{1}$, ACHILLE C. PESSINA ${ }^{1}$ and GASTONE G. NUSSDORFER ${ }^{3}$ \\ Departments of ${ }^{1}$ Clinical and Experimental Medicine (DMCS-Internal Medicine 4), \\ ${ }^{2}$ Medical and Surgical Sciences (Surgical Pathology) and ${ }^{3}$ Human Anatomy and Physiology \\ (Section of Anatomy), School of Medicine, University of Padua, I-35121 Padua, Italy
}

Received December 19, 2005; Accepted February 7, 2006

\begin{abstract}
Adiponectin is an adipocyte-derived circulating peptide that plays an important role in adipose tissue metabolism, insulin sensitivity and cardiovascular disease. The adrenal gland, by secreting glucorticoid and mineralocorticoid hormones, intervenes in cardiovascular and glucose metabolism regulation and is surrounded by adipose tissue. Hence, we investigated the hypothesis that adiponectin receptor types 1 and 2 (adipo-R1 and adipo-R2) are expressed in the human adrenal gland and in adrenocortical zona glomerulosa cell-derived aldosterone-producing adenoma (APA) tissue. We used real-time reverse transcription-polymerase chain reaction to demonstrate the mRNA of adipo-R1 and adipo-R2 in 10 histologically normal human adrenal cortexes that were obtained from patients with renal cancer undergoing nephrectomy with ipsilateral adrenalectomy and in 10 APAs. Melting curve analysis and sequencing were used to confirm the specificity of the amplicons obtained. Results consistently showed the expression of specific mRNAs of adiponectin receptors in all histologically normal human adrenal cortexes and APAs. This novel finding suggests that adiponectin could play a regulatory role in adrenocortical function and growth in humans.
\end{abstract}

\section{Introduction}

Adiponectin, an adipose tissue derived peptide (1, reviewed in ref. 2), exerts anti-inflammatory and anti-atherogenic effects by inhibiting crucial steps of atherogenesis (3-6), stimulating nitric oxide production (7) and blunting the expression of adhesins on the endothelium (3, reviewed in ref. 8). The

Correspondence to: Professor Gian Paolo Rossi, Department of Clinical and Experimental Medicine, Clinica Medica 4 University Hospital, via Giustiniani 2, I-35126 Padova, Italy

E-mail: gianpaolo.rossi@unipd.it

Key words: adiponectin receptors, adrenal cortex, aldosteroneproducing adenomas, humans evidence linking blood adiponectin levels with arterial hypertension remains conflicting (9-14), even though low plasma adiponectin concentrations have been implicated in endothelial dysfunction, a hallmark of arterial hypertension and other conditions associated with high cardiovascular risk $(15,16)$. Low plasma adiponectin levels have been also described in obesity, where they increase during weight reduction (17-19) and in type 2 diabetes (20). Moreover, because supplying physiological doses of recombinant adiponectin were found to correct hyperinsulinemia and insulin resistance (21), low plasma adiponectin concentrations have been suggested to play a causal role in insulin resistance $(18,22,23)$. Therefore, blunted blood adiponectin levels would appear to be a hallmark of high cardiovascular risk conditions and hyperinsulinemia.

Two recently identified adiponectin receptor subtypes, referred to as adipo-R1 and adipo-R2, mediate the biological effects of adiponectin. The cloning and sequencing of the genes coding these receptor subtypes have been recently accomplished, thus providing novel opportunities for the investigation of their tissue distribution at the mRNA level $(2,24)$. As the adrenal gland is not only exposed to circulating adiponectin but is deeply embedded in adipose tissue, endocrine-paracrine interactions might exist between the adrenal cortex and adipocytes. Hence, we decided to test the hypothesis that adipo-R1 and adipo-R2 genes are expressed in the histologically normal human adrenal cortex and in tumors that are derived from the adrenal zona glomerulosa.

\section{Materials and methods}

Adrenal specimens. Histologically normal adrenocortical tissue was obtained at surgery from 10 patients with renal cancer undergoing unilateral nephrectomy and ipsilateral adrenalectomy. Furthermore, 10 patients with an aldosteroneproducing adenoma (APA) were enrolled. In these patients the diagnosis was based on strict predefined criteria that were based on lateralization of aldosterone secretion at adrenal vein sampling, on surgery, pathology and, more importantly, follow-up data. For the latter, we required demonstration of normokaliemia and, according to the AHA guidelines (25), cure or improvement of hypertension at least 120 days after adrenalectomy. Cure was defined as a systolic blood pressure 
Table I. Anthropometric and biochemical features of the patients with APA.

\begin{tabular}{ll}
\hline Age (years) & $52 \pm 12$ \\
$\begin{array}{l}\text { Gender (male/female) } \\
\begin{array}{l}\text { Systolic blood pressure } \\
\text { (mmHg) }\end{array}\end{array}$ & $4 / 6$ \\
$\begin{array}{l}\text { Diastolic blood } \\
\text { pressure (mmHg) }\end{array}$ & $107 \pm 11$ \\
$\begin{array}{l}\text { Serum } \mathrm{K}^{+} \text {concentration } \\
\text { (mmol/l) }\end{array}$ & $3.1 \pm 0.5[3.6-4.5]$ \\
$\begin{array}{l}\text { Plasma renin activity } \\
\text { (ng Ang-I/ml/h) }\end{array}$ & $0.19(0.09-0.36)[0.65-2.65]$ \\
$\begin{array}{l}\text { Aldosterone plasma } \\
\text { concentration (pg/ml) }\end{array}$ & $397(221-660)[<110]$ \\
$\begin{array}{l}\text { Cortisol plasma } \\
\text { concentration (ng/ml) }\end{array}$ & $147(46-259)[<46]$ \\
$\begin{array}{l}\text { ACTH plasma } \\
\text { concentration (pg/ml) }\end{array}$ & $13.2(4.5-46.3)[15-22]$ \\
\hline
\end{tabular}

Means \pm SEM, $n=10$; ranges in parentheses. Normal values are shown in square brackets.

of $<140 \mathrm{mmHg}$ and diastolic blood pressure of $<90 \mathrm{mmHg}$ without medications; and improvement as a systolic and diastolic blood pressure of $<140 / 90 \mathrm{mmHg}$, respectively, on the same or reduced number of medications and/or reduced defined daily doses, as described by the World Health Organization (26). The main anthropometric and clinical features of patients with APA are shown in Table I. Tissue specimens were obtained at surgery under sterile conditions, immediately frozen in liquid nitrogen, and stored at $-80^{\circ} \mathrm{C}$ until extraction, as previously described (27). Peri-adrenal adipose tissue obtained from three APA patients was similarly processed as control.
Measurement of adiponectin-receptor mRNAs. Total RNA was isolated from frozen tissue using the guanidine isothiocyanate method (Omnizol Kit ${ }^{\mathrm{TM}}$, EuroClone, Milan, Italy). The method used to investigate adipo-R1 and adipo-R2 mRNAs entails a novel real-time reverse transcription (RT)-polymerase chain reaction (PCR) that was applied for the first time in this study. We used the LightCycler Instrument ${ }^{\mathrm{TM}}$ and LightCycler Design Probe $^{\mathrm{TM}}$ software (both from Roche, Monza, Italy). For this approach, it is crucial that the RNA preparation is free of contaminating DNA which can lead to overestimation of the amount of RNA. Hence, the quality of the RNA was systematically checked using lab-on-a-chip technology in an Agilent Bio-analyzer 2100 with the RNA6000 nano assay (Agilent Technologies, Palo Alto, CA). To exclude the possibility of cross-amplification between the two genes, which share $67 \%$ homology (2), we blasted the mRNA sequences of the adipo-R1 versus adipo-R2 to identify the homologous regions; then, we designed primers that were selective for each adiponectin receptor gene. Primers were chosen to span exon-intron boundaries, in order to prevent occurrence of co-amplification of genomic DNA. Adipo-R1 and adipo-R2 $(1 \mu \mathrm{g})$ encoding mRNA was reverse-transcribed with Iscript ${ }^{\mathrm{TM}}$ (Bio-Rad, Milan, Italy), and $2 \mu \mathrm{l}$ of each RT reaction was amplified with specific primers by using a Fast Start SYBR-Green Plus Kit ${ }^{\mathrm{TM}}$ (Roche) in a glass capillary according to the manufacturer's instructions. The mRNA encoding for porphobilinogen deaminase (PBGD) was similarly processed for use as a housekeeping gene in a separate onestep RT-PCR, as detailed earlier (28). This served as a control for RT-PCR performance. Primer sequences are shown in Table II. Cycle conditions were the same for all genes tested: initial denaturation at $95^{\circ} \mathrm{C}$ for $10 \mathrm{~min}$, followed by 40 PCR cycles consisting of $95^{\circ} \mathrm{C}$ for $5 \mathrm{sec}, 58^{\circ} \mathrm{C}$ for $10 \mathrm{sec}$ and $72^{\circ} \mathrm{C}$ for $15 \mathrm{sec}$. SYBR-Green I fluorescence emissions were monitored after each cycle. Expression of adipo-R1, adipo-R2 and PBGD mRNA was quantified by the second derivative maximum method of the LightCycler software (Roche), by determining the crossing points of individual samples by an algorithm which identifies the first turning point of the fluorescence curve. Adipo-R1 and adipo-R2 expression was calculated relative to PBGD, which was used as an internal control. Amplification of specific transcripts was confirmed by melting curve profiles (cooling the sample to $50^{\circ} \mathrm{C}$ and

Table II. RT-PCR primers and PCR products.

\begin{tabular}{llll}
\hline Primers & \multicolumn{1}{c}{ Sequence } & Accession no. & Amplicon size (bp) \\
\hline $\begin{array}{l}\text { Adipo-R1 } \\
\text { Sense }\end{array}$ & & \\
Antisense & 5'-CCAAAGCTGAAGAAGAGCAAA-3' & NM_015999 & 134 \\
Adipo-R2 & 5'-TCCCTCCCAGACCTTGTA-3' & & \\
$\quad$ Sense & 5'-ACATCTGGTTTCACTCTCATC-3' & NM_024551 \\
Antisense & 5'-ATCAGTAGCCAGCAGGGA-3' & & \\
PBGD & & & 463 \\
Sense & 5'-TGCCAGAGAAGAGTGTGGT-3' \\
Antisense & 5'-ATGCTATCTGAGCCGTCT-3' & NM_000190 \\
\hline
\end{tabular}



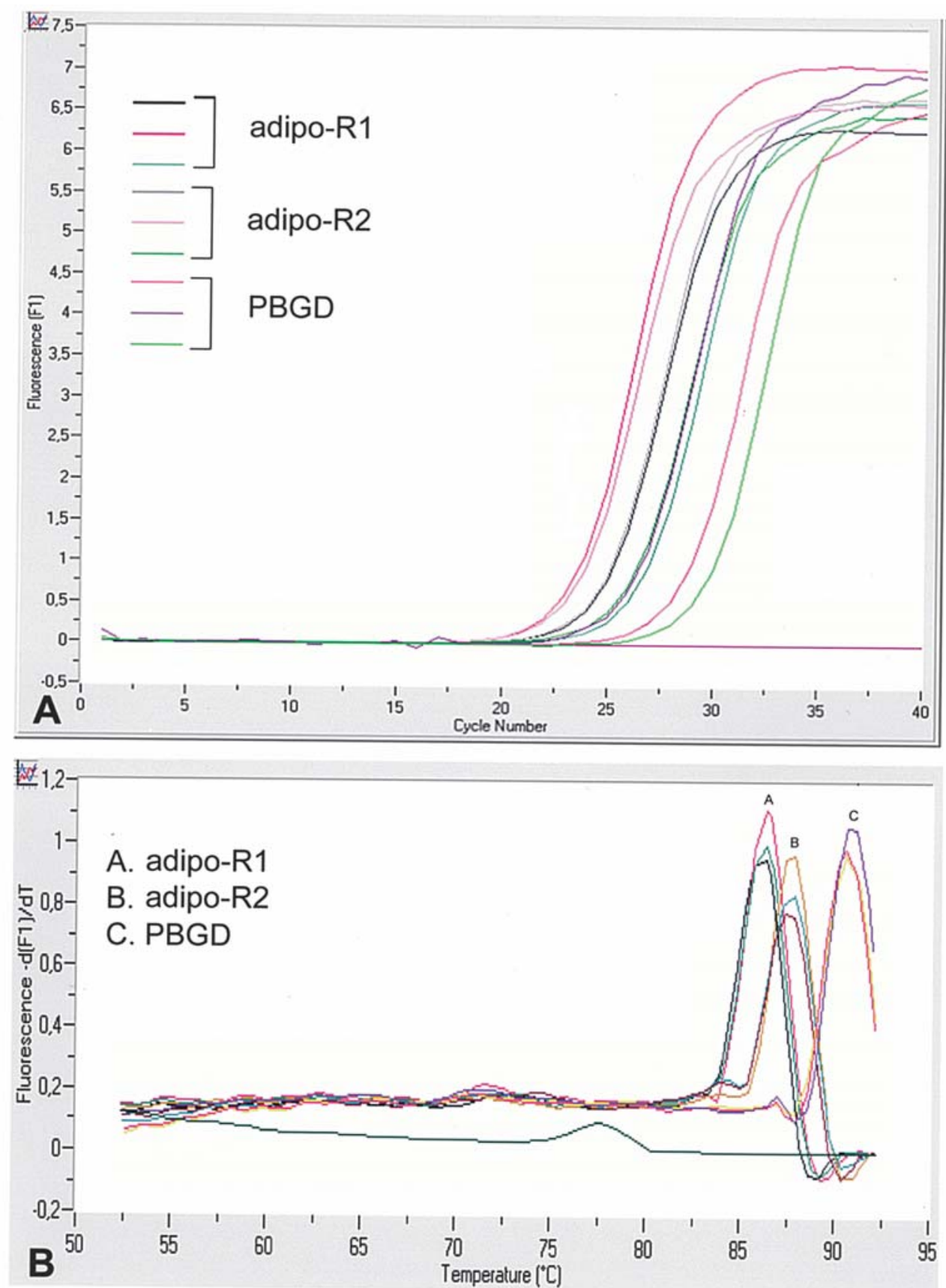

Figure 1. Exemplary results of real-time PCR amplification of adipo-R1 and adipo-R2 from three different specimens of histologically normal adrenal cortex (A). Corresponding melting curve results, which suggest the specificity of the amplicons and the lack of contaminants (B).

heating slowly to $95^{\circ} \mathrm{C}$ with measurement of fluorescence) at the end of each PCR cycle, using the specific routine built-up in the LightCycler instrument. The specificity of the PCR was further verified by sequencing analysis. The products of PCR were cleaned using a GenElute ${ }^{\mathrm{TM}}$ PCR Clean-up kit (Sigma-Aldrich Corp., St. Louis, MO), dehydrated, reamplified using the original primers, and sequenced by the BigDye Terminator cycle sequencing reaction and an ABI PRISM 3100 Genetic Analyzer with support from CRIBI (Centro Ricerca Interdipartimentale Biotecnologie Innovative) at the University of Padua, Italy. Quantification of gene expression was carried out relative to PBGD by determining the threshold cycle $(\mathrm{Ct})$ of the target genes, as described previously (29).
Statistical analysis. Comparison of the expression of adipo-R1 and adipo-R2 genes between the normal adrenal cortex and APA tissue was performed using the non-parametric MannWhitney test. Statistical analysis was performed using SPSS for Windows software (Vers. 13.0, SPSS Italy Inc., Bologna, Italy).

\section{Results}

The novel real-time RT-PCR methodology developed in this study illustrates the feasibility of detecting adipo-R1 and adipo-R2 gene specific mRNAs in human tissues (Fig. 1A). The melting curve analysis revealed a clean well-defined peak (Fig. 1B) at the temperature of 86.3 and $87.7^{\circ} \mathrm{C}$ for the 
adipo-R1

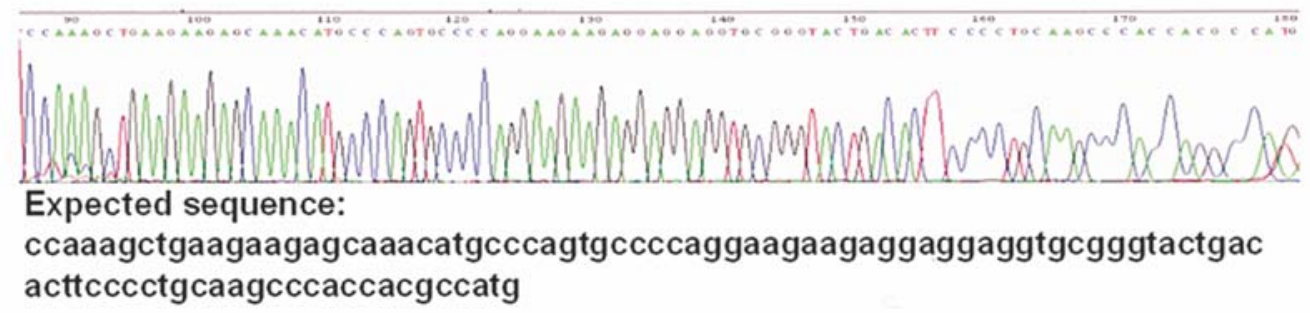

adipo-R2

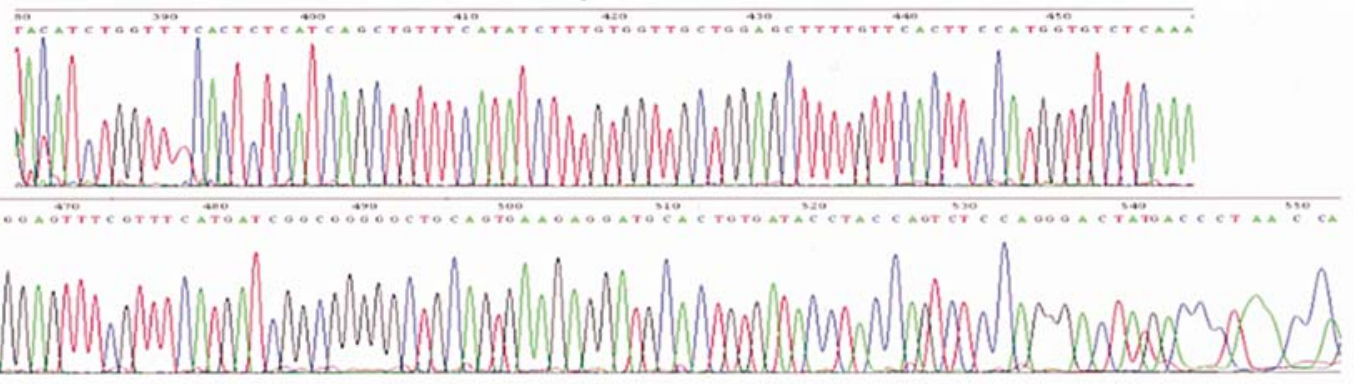

\section{Expected sequence: acatctggtttcactctcatcagctgtttcatatctttgtggttgctggagctttgttcacttccatggtgtctcaaacctcc aggagtttcgtttcatgatcggcgggggctgcagtgaagaggatgcactgtgatacctaccagtctccagggactat gaccctaaacca}

Figure 2. Results of sequencing of real-time PCR amplification products of adiponectin receptor subtypes.

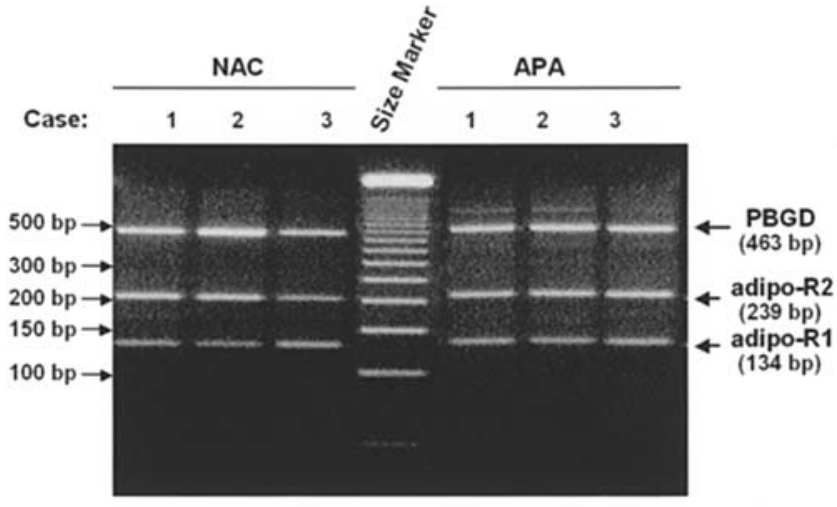

Figure 3. Ethidium bromide-stained 3\% gel electrophoresis showing exemplary results of RT-PCR in three histologically normal human adrenal cortex (NAC) specimens and in three APA tissues. Lanes were loaded with amplification products of all three genes (adipo-R1, adipo-R2 and PBGD).

adipo-R1 and adipo-R2 genes, respectively, thus ruling out the amplification of non-specific products. Furthermore, the sequencing of the amplicons conclusively confirmed the exact correspondence between the obtained and the expected sequences (Fig. 2).

This methodology allowed the detection of specific mRNAs of adipo-R1 and adipo-R2 genes, not only in adipose tissue but also in adrenocortical tissue specimens. Histologically normal adrenocortical tissue (Figs. 1 and 3), APA specimens (Fig. 3) and control adipose tissue (data not shown) were found to consistently express both adiponectin receptor subtypes. Results of quantification relative to the housekeeping gene, PBGD, showed that both the adipo-R1 and the adipo-R2
mRNAs were expressed at a significantly higher level in APAs than in the normal adrenal cortex (Fig. 4).

\section{Discussion}

The intimate relationship between the amount of adipose tissue on one hand and the sensitivity to insulin, and blood pressure levels on the other, suggests the hypothesis that adipose tissue modulates the release of hormones that are involved in glucose metabolism. The present results demonstrate for the first time that the genes of the two known adiponectin receptor subtypes are expressed in the normal human adrenal cortex. Hence, the possibility of a cross-talk between adipose tissue and the adrenal cortex is suggested. However, as we used RNA extracted from tissue homogenates, our gene expression experiments do not allow any precise localization of adiponectin receptors in the human adrenal cortex. Moreover, they do not conclusively prove that these receptor subtypes are functionally expressed at the protein level. Accordingly, studies with in situ hybridization, immunocytochemistry, autoradiography and binding displacement are necessary to address these limitations.

Other peptides produced by adipocytes, e.g. leptin (30-34) and beacon (35-38), or regulating fat metabolism and energy homeostasis, e.g. orexins (39-42), neuropeptide-Y (43), neuropeptides-B and -W $(44,45)$ and cholecystokinin (46-48), may control adrenal functions. Hence, it is tempting to hypothesize that adiponectin can regulate the release of cortisol and aldosterone from the adrenal cortex, with ensuing effects on gluconeogenesis, fat deposition, insulin sensitivity, electrolyte and water homeostasis, and ultimately on blood pressure levels.

By studying high cardiovascular risk patients, we recently found, in accordance with previous studies $(13,49)$, that body 

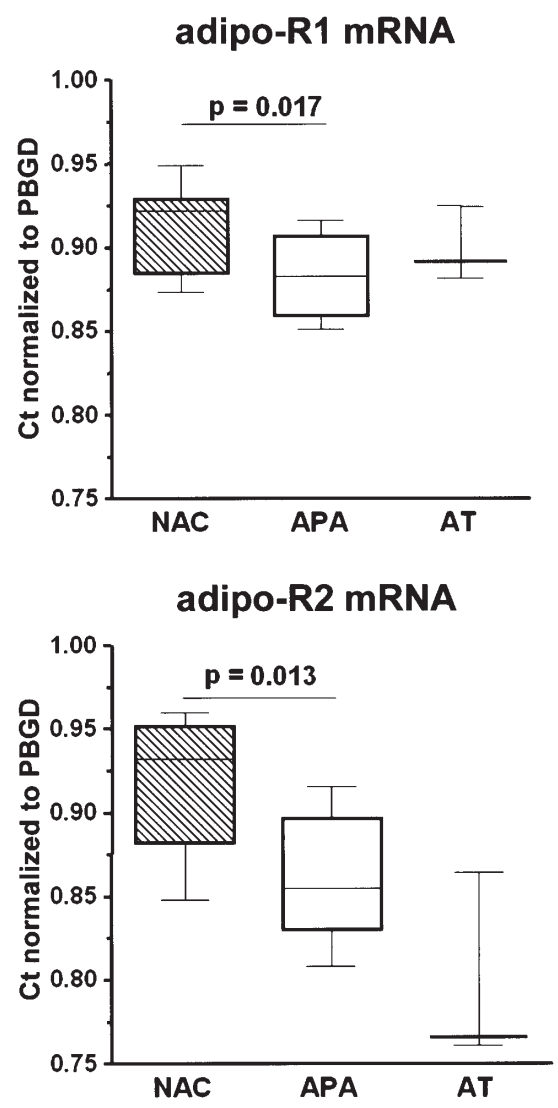

Figure 4. The graphs show the median, interquartile range and extreme values of the expression of adipo-R1 and adipo- $\mathrm{R} 2$ relative to the housekeeping gene PBGD measured with real-time PCR in the histologically normal human adrenal cortex (NAC), APA and adipose tissue (AT). The significantly lower $\mathrm{Ct}$ ratio of APA tissue for both adipo-R1 and adipo-R2 indicates a higher mRNA expression level as compared to NAC.

mass index, along with other variables, significantly predicts plasma adiponectin levels (unpublished results). Thus, the present demonstration of adiponectin receptors in the adrenal cortex may explain a functional link between body mass index (e.g. the amount of adipose tissue), blood pressure and the adrenal cortex. It has to be acknowledged, however, that the evidence from cross-sectional studies implicating plasma adiponectin in arterial hypertension is conflicting (11-14), and there are no data linking adiponectin to aldosterone secretion. Therefore, the hypothesis that adiponectin can modulate aldosterone secretion by acting on adiponectin receptor subtypes in the adrenal cortex remains to be addressed. The present results show that both adipo-R1 and the adipo-R2 genes are expressed at a higher level in APAs than in the normal adrenal cortex, a finding that merits further study.

In summary, our results document for the first time the gene expression of the adiponectin receptor subtypes in the human adrenal cortex and, at a higher level, in APA tissue. While the functional significance of this finding remains to be investigated, the possibility that adipose tissue can regulate the function of the human adrenal cortex is suggested.

\section{Acknowledgements}

This study was supported by research grants from Unindustria of Treviso and F.O.R.I.C.A. to professor G.P. Rossi.

\section{References}

1. Maeda K, Okubo K, Shimomura I, Funahashi T, Matsuzawa Y and Matsubara K: cDNA cloning and expression of a novel adipose specific collagen-like factor, apM1 (AdiPose Most abundant Gene transcript 1). Biochem Biophys Res Commun 221: 286-289, 1996.

2. Kadowaki $\mathrm{T}$ and Yamauchi $\mathrm{T}$ : Adiponectin and adiponectin receptors. Endocr Rev 26: 439-451, 2005.

3. Ouchi N, Kihara S, Arita Y, Okamoto Y, Maeda K, Kuriyama H, Hotta K, Nishida M, Takahashi M, Muraguchi M, Ohmoto Y, Nakamura T, Yamashita S, Funahashi T and Matsuzawa Y: Adiponectin, an adipocyte-derived plasma protein, inhibits endothelial $\mathrm{NF}_{-\kappa \mathrm{B}}$ signaling through a cAMP-dependent pathway. Circulation 102: 1296-1301, 2000.

4. Ouchi N, Kihara S, Arita Y, Nishida M, Matsuyama A, Okamoto Y, Ishigami M, Kuriyama H, Kishida K, Nishizawa H, Hotta K, Muraguchi M, Ohmoto Y, Yamashita S, Funahashi T and Matsuzawa Y: Adipocyte-derived plasma protein, adiponectin, suppresses lipid accumulation and class A scavenger receptor expression in human monocyte-derived macrophages. Circulation 103: 1057-1063, 2001.

5. Okamoto Y, Arita Y, Nishida M, Muraguchi M, Ouchi N, Takahashi M, Igura T, Inui Y, Kihara S, Nakamura T, Yamashita S, Miyagawa J, Funahashi T and Matsuzawa Y: An adipocyte-derived plasma protein, adiponectin, adheres to injured vascular walls. Horm Metab Res 32: 47-50, 2000.

6. Arita Y, Kihara S, Ouchi N, Maeda K, Kuriyama H, Okamoto Y, Kumada M, Hotta K, Nishida M, Takahashi M, Nakamura T, Shimomura I, Muraguchi M, Ohmoto Y, Funahashi T and Matsuzawa Y: Adipocyte-derived plasma protein adiponectin acts as a platelet-derived growth factor-BB-binding protein and regulates growth factor-induced common postreceptor signal in vascular smooth muscle cell. Circulation 105: 2893-2898, 2002.

7. Chen H, Montagnani M, Funahashi T, Shimomura I and Quon MJ: Adiponectin stimulates production of nitric oxide in vascular endothelial cells. J Biol Chem 278: 45021-45026, 2003.

8. Berg AH and Scherer PE: Adipose tissue, inflammation and cardiovascular disease. Circ Res 96: 939-949, 2005.

9. Mallamaci F, Zoccali C, Cuzzola F, Tripepi G, Cutrupi S, Parlongo S, Tanaka S, Ouchi N, Kihara S, Funahashi T and Matsuzawa Y: Adiponectin in essential hypertension. J Nephrol 15: 507-511, 2002.

10. Adamczak M, Wiecek A, Funahashi T, Chudek J, Kokot F and Matsuzawa Y: Decreased plasma adiponectin concentration in patients with essential hypertension. Am J Hypertens 16: 72-75, 2003.

11. Kazumi T, Kawaguchi A, Sakai K, Hirano T and Yoshino G: Young men with high-normal blood pressure have lower serum adiponectin, smaller LDL size, and higher elevated heart rate than those with optimal blood pressure. Diabetes Care 25: 971-976, 2002.

12. Furuhashi M, Ura N, Higashiura K, Murakami H, Tanaka M, Moniwa N, Yoshida D and Shimamoto K: Blockade of the renin-angiotensin system increases adiponectin concentrations in patients with essential hypertension. Hypertension 42: 76-81, 2003.

13. Iwashima Y, Katsuya T, Ishikawa K, Ouchi N, Ohishi M, Sugimoto K, Fu Y, Motone M, Yamamoto K, Matsuo A, Ohashi K, Kihara S, Funahashi T, Rakugi H, Matsuzawa Y and Ogihara T: Hypoadiponectinemia is an independent risk factor for hypertension. Hypertension 43: 1318-1323, 2004.

14. Yilmaz MI, Sonmez A, Kilic S, Celik T, Bingol N, Pinar M, Mumcuoglu T and Ozata M: The association of plasma adiponectin levels with hypertensive retinopathy. Eur J Endocrinol 152: 233-240, 2005.

15. Ouchi N, Ohishi M, Kihara S, Funahashi T, Nakamura T, Nagaretani H, Kumada M, Ohashi K, Okamoto Y, Nishizawa H, Kishida K, Maeda N, Nagasawa A, Kobayashi H, Hiraoka H, Komai N, Kaibe M, Rakugi H, Ogihara T and Matsuzawa Y: Association of hypoadiponectinemia with impaired vasoreactivity. Hypertension 42: 231-234, 2003.

16. Brunner H, Cockcroft JR, Deanfield J, Donald A, Ferrannini E, Halcox J, Kiowski W, Luscher TF, Mancia G, Natali A, Oliver JJ, Pessina AC, Rizzoni D, Rossi GP, Salvetti A, Spieker LE, Taddei S and Webb DJ: Endothelial function and dysfunction. Part II: Association with cardiovascular risk factors and diseases. A statement by the Working Group on Endothelins and Endothelial Factors of the European Society of Hypertension. J Hypertens 23: 233-246, 2005. 
17. Arita Y, Kihara S, Ouchi N, Takahashi M, Maeda K, Miyagawa J, Hotta K, Shimomura I, Nakamura T, Miyaoka K, Kuriyama H, Nishida M, Yamashita S, Okubo K, Matsubara K, Muraguchi M, Ohmoto Y, Funahashi T and Matsuzawa Y: Paradoxical decrease of an adipose-specific protein, adiponectin, in obesity. Biochem Biophys Res Commun 257: 79-83, 1999.

18. Weyer C, Funahashi T, Tanaka S, Hotta K, Matsuzawa Y, Pratley RE and Tataranni PA: Hypoadiponectinemia in obesity and type 2 diabetes: close association with insulin resistance and hyperinsulinemia. J Clin Endocrinol Metab 86: 1930-1935, 2001.

19. Yang WS, Lee WJ, Funahashi T, Tanaka S, Matsuzawa $Y$, Chao CL, Chen CL, Tai TY and Chuang LM: Weight reduction increases plasma levels of an adipose-derived anti-inflammatory protein, adiponectin. J Clin Endocrinol Metab 86: 3815-3819, 2001.

20. Hotta K, Funahashi T, Arita Y, Takahashi M, Matsuda M, Okamoto Y, Iwahashi H, Kuriyama H, Ouchi N, Maeda K, Nishida M, Kihara S, Sakai N, Nakajima T, Hasegawa K, Muraguchi M, Ohmoto Y, Nakamura T, Yamashita S, Hanafusa T and Matsuzawa Y: Plasma concentrations of a novel, adiposespecific protein, adiponectin, in type 2 diabetic patients. Arterioscler Thromb Vasc Biol 20: 1595-1599, 2000.

21. Yamauchi T, Kamon J, Waki H, Terauchi Y, Kubota N, Hara K, Mori Y, Ide T, Murakami K, Tsuboyama-Kasaoka N, Ezaki O, Akanuma Y, Gavrilova O, Vinson C, Reitman ML, Kagechika H, Shudo K, Yoda M, Nakano Y, Tobe K, Nagai R, Kimura S, Tomita M, Froguel P and Kadowaki T: The fat-derived hormone adiponectin reverses insulin resistance associated with both lipoatrophy and obesity. Nat Med 7: 941-946, 2001.

22. Steffes MW, Gross MD, Schreiner PJ, Yu X, Hilner JE, Gingerich R and Jacobs DR Jr: Serum adiponectin in young adults. Interactions with central adiposity, circulating levels of glucose and insulin resistance: the CARDIA study. Ann Epidemiol 14: 492-498, 2004.

23. Pajvani UB and Scherer PE: Adiponectin: systemic contributor to insulin sensitivity. Curr Diab Rep 3: 207-213, 2003.

24. Yamauchi T, Kamon J, Ito Y, Tsuchida A, Yokomizo T, Kita S, Sugiyama T, Miyagishi M, Hara K, Tsunoda M, Murakami K, Ohteki T, Uchida S, Takekawa S, Waki H, Tsuno NH, Shibata Y, Terauchi Y, Froguel P, Tobe K, Koyasu S, Taira K, Kitamura T, Shimizu T, Nagai R and Kadowaki T: Cloning of adiponectin receptors that mediate antidiabetic metabolic effects. Nature 423: 762-769, 2003.

25. Rundback JH, Sacks D, Kent KC, Cooper C, Jones D, Murphy T, Rosenfield K, White C, Bettmann M, Cortell S, Puschett J, Clair D and Cole P: Guidelines for the reporting of renal artery revascularization in clinical trials. Circulation 106: 1572-1585, 2002.

26. World Health Organization-International Society of Hypertension Guidelines for the Management of Hypertension. Guidelines Subcommittee. J Hypertens 17: 151-183, 1999.

27. Rossi G, Albertin G, Belloni A, Zanin L, Biasolo MA, Prayer GT, Bader M, Nussdorfer GG, Palu G and Pessina AC: Gene expression, localization and characterization of endothelin A and $\mathrm{B}$ receptors in the human adrenal cortex. J Clin Invest 94 : 1226-1234, 1994

28. Cesari M, Zanchetta M, Burlina A, Pedon L, Maiolino G, Sticchi D, Pessina AC and Rossi GP: Hyperhomocysteinemia is inversely related with left ventricular ejection fraction and predicts cardiovascular mortality in high-risk coronary artery disease hypertensives. Arterioscler Thromb Vasc Biol 25: $115-121,2005$

29. Sticchi D, Fassina A, Ganzaroli C, Pasqualetto C, Pessina AC, Nussdorfer GG and Rossi GP: Expression of telomerase (hTERT) in aldosterone-producing adrenocortical tumors. Int J Mol Med 17: 469-474, 2006.

30. Bornstein SR, Uhlmann K, Haidan A, Ehrhart-Bornstein M and Scherbaum WA: Evidence for a novel peripheral action of leptin as a metabolic signal to the adrenal gland: leptin inhibits cortisol release directly. Diabetes 46: 1235-1238, 1997.

31. Glasow A and Bornstein SR: Leptin and the adrenal gland. Eur J Clin Invest 3: 39-45, 2000.

32. Malendowicz LK, Gorska T, Tortorella C, Nowak M, Majchrzak M, Spinazzi R, Nussdorfer GG and Nowak KW: Acute in vivo effects of leptin and leptin fragments on corticosteroid hormone secretion and entero-insular axis in the rat. Int $\mathbf{J}$ Mol Med 13: 829-834, 2004.
33. Malendowicz LK, Spinazzi R, Tortorella C, Nussdorfer GG, Ziolkowska A and Rucinski M: Effects of leptin and leptin fragments on corticosterone secretion and growth of cultured rat adrenocortical cells. Int J Mol Med 14: 873-878, 2004.

34. Markowska A, Neri G, Hochol A, Nowak M, Nussdorfer GG and Malendowicz LK: Effects of leptin and leptin fragments on steroid secretion and proliferative activity of regenerating rat adrenal cortex. Int J Mol Med 13: 139-141, 2004

35. Ziolkowska A, Carraro G, Rebuffat P, Spinazzi R, Nussdorfer GG, Rucinski M and Malendowicz LK: Beacon[47-73] inhibits glucocorticoid secretion and growth of cultured rat and human adrenocortical cells. Int J Mol Med 14: 457-461, 2004.

36. Ziolkowska A, Rucinski M, Di Liddo R, Nussdorfer GG and Malendowicz LK: Expression of the beacon gene in endocrine glands of the rat. Peptides 25: 133-137, 2004.

37. Ziolkowska A, Rucinski M, Neri G, Di Liddo R, Nussdorfer GG and Malendowicz LK: Expression of the beacon gene in the rat adrenal gland: direct inhibitory effect of beacon[47-73] on aldosterone secretion from dispersed adrenal zona glomerulosa cells. Int J Mol Med 13: 215-219, 2004.

38. Rucinski M, Andreis PG, Ziolkowska A, Nussdorfer GG and Malendowicz LK: Differential expression and function of beacon in the rat adrenal cortex and medulla. Int J Mol Med 16: 35-40, 2005.

39. Malendowicz LK, Tortorella C and Nussdorfer GG: Orexins stimulate corticosterone secretion of rat adrenocortical cells, through the activation of the adenylate cyclase-dependent signaling cascade. J Steroid Biochem Mol Biol 70: 185-188, 1999.

40. Mazzocchi G, Malendowicz LK, Gottardo L, Aragona F and Nussdorfer GG: Orexin A stimulates cortisol secretion from human adrenocortical cells through activation of the adenylate cyclase-dependent signaling cascade. J Clin Endocrinol Metab 86: 778-782, 2001.

41. Spinazzi R, Rucinski M, Neri G, Malendowicz LK and Nussdorfer GG: Preproorexin and orexin receptors are expressed in cortisol-secreting adrenocortical adenomas and orexins stimulate in vitro cortisol secretion and growth of tumor cells. J Clin Endocrinol Metab 90: 3544-3549, 2005.

42. Spinazzi R, Ziolkowska A, Neri G, Nowak M, Rebuffat P, Nussdorfer GG, Andreis PG and Malendowicz LK: Orexins modulate the growth of cultured rat adrenocortical cells, acting through type 1 and type 2 receptors coupled to the MAPK p42/ p44- and p38-dependent cascades. Int J Mol Med. 15: 847-852, 2005.

43. Spinazzi R, Andreis PG and Nussdorfer GG: Neuropeptide-Y and Y-receptors in the autocrine-paracrine regulation of adrenal gland under physiological and pathophysiological conditions. Int J Mol Med 15: 3-13, 2005.

44. Hochol A, Albertin G, Nussdorfer GG, Spinazzi R, Ziolkowska A, Rucinski M and Malendowicz LK: Effects of neuropeptides B and $\mathrm{W}$ on the secretion and growth of rat adrenocortical cells. Int J Mol Med 14: 843-847, 2004.

45. Mazzocchi G, Rebuffat P, Ziolkowska A, Rossi GP, Malendowicz LK and Nussdorfer GG: G protein receptors 7 and 8 are expressed in human adrenocortical cells, and their endogenous ligands neuropeptides $\mathrm{B}$ and $\mathrm{W}$ enhance cortisol secretion by activating adenylate cyclase- and phospholipase C-dependent signaling cascades. J Clin Endocrinol Metab 90: 3466-3471, 2005.

46. Malendowicz LK, Nowak M, Gottardo L, Tortorella C, Majchrzak M and Nussdorfer GG: Cholecystokinin stimulates aldosterone secretion from dispersed rat zona glomerulosa cells, acting through cholecystokinin receptors 1 and 2 coupled with the adenylate cyclase-dependent cascade. Endocrinology 142: 4251-4255, 2001

47. Mazzocchi G, Malendowicz LK, Aragona F, Spinazzi R and Nussdorfer GG: Cholecystokinin (CCK) stimulates aldosterone secretion from human adrenocortical cells via CCK2 receptors coupled to the adenylate cyclase/protein kinase A signaling cascade. J Clin Endocrinol Metab 89: 1277-1284, 2004.

48. Nussdorfer GG, Spinazzi R and Mazzocchi G: Cholecystokinin and adrenal-cortex secretion. Vitam Horm 71: 433-453, 2005.

49. Rothenbacher D, Brenner H, Marz W and Koenig W: Adiponectin, risk of coronary heart disease and correlations with cardiovascular risk markers. Eur Heart J 26: 1640-1646, 2005. 